\title{
Phylogenetic analysis and biolistic infectivity of a cloned Sri Lankan cassava mosaic virus DNA-A from Tamil Nadu, India on Nicotiana benthamiana
}

\author{
A. K. KUSHAWAHA ${ }^{1}$, R. RABINDRAN², I. DASGUPTA ${ }^{1 *}$
}

\begin{abstract}
${ }^{1}$ Department of Plant Molecular Biology, University of Delhi South Campus, Benito Juarez Road, New Delhi-110021, India, ${ }^{2}$ Center for Plant Breeding and Genetics, Tamil Nadu Agricultural University, Coimbatore, Tamil Nadu-641003, India
\end{abstract}

Received August 13, 2014; accepted February 11, 2015

\begin{abstract}
Summary. - The complete nucleotide sequence of Sri Lankan cassava mosaic virus (SLCMV) DNA-A isolated from cassava in southern India was analyzed, a phylogenetic analysis with other begomoviral nucleotide sequences was performed and an efficient inoculation method of Nicotiana benthamiana with the cloned DNA was developed utilizing a biolistic device. The nucleotide sequence showed the conservation of all functional begomoviral protein domains and aligned most closely with begomoviruses reported from the Indian subcontinent, except for begomoviruses of cucurbits and legumes. Upon biolistic inoculation of N. benthamiana with the cloned DNA, most plants became symptomatic and showed the accumulation of viral DNA within 21-28 days post-inoculation.
\end{abstract}

Keywords: cassava; begomovirus; rolling circle amplification; dendrogram; biolistic inoculation

\section{Introduction}

Geminiviruses (the family Geminiviridae) cause significant yield losses in crop plants throughout the tropical and sub-tropical parts of the world (Thresh et al., 1997; Patil and Fauquet, 2009; Castillo et al., 2011). Members of the genus Begomovirus (the family Geminiviridae) are transmitted by whiteflies of the species Bemisia tabaci (Sanderfoot and Lazarowitz, 1996) and consist of one (monopartite) or two (bipartite) circular single-stranded DNA components of about $2.7 \mathrm{~kb}$ in size. DNA-A components encode proteins necessary, among others, in replication and encapsidation; whereas DNA-B encodes proteins with functions related to the movement of viral DNA within and between the host cell (Kheyr-Pour et al., 1991; Fauquet et al., 2008). There is

*Corresponding author. E-mail: indranil58@yahoo.co.in, indasgup@south.du.ac.in; phone: +91-11-24111639, +91-11-24116113 (Office), +919910334110 (Mobile).

Abbreviations: $\mathrm{CMD}=$ cassava mosaic disease; $\mathrm{psi}=$ pounds per square inch; $\mathrm{RCA}=$ rolling circle amplification; $\mathrm{SLCMV}=\mathrm{Sri}$ Lankan cassava mosaic virus an approximately $200 \mathrm{bp}$ common region (CR) within the intergenic region of both DNA components, which share high similarity with each other (Harrison and Robinson, 1999). The common region is important for the initiation of DNA replication. The proteins encoded by DNA-A include the coat protein (AV1), the replication-associated protein $\mathrm{AC1}$ (Rep), and the remaining proteins that have roles as a pathogenicity determinant (AC2), enhancer of viral DNA accumulation (AC3) and symptom determinant (AC4) in various begomoviruses (Morris et al., 1991; Azzam et al., 1994; Jupin et al., 1995; Sung and Coutts, 1995; Vanitharani et al., 2004). AC2 and AC4 have also been reported to act as suppressors of RNAi, a defence response of plants against viruses, thus contributing towards the viral virulence functions (Vanitharani et al., 2004).

Cassava mosaic disease (CMD) is widespread in cassava (Manihot esculenta Crantz, the family Euphorbiaceae) in the African continent, India and Sri Lanka (Abraham, 1956, Alagianagalingam and Ramakrishnan, 1966). Two bipartite begomoviruses, Indian cassava mosaic virus (ICMV) and Sri Lankan cassava mosaic virus (SLCMV) are associated with CMD in India (Saunders et al., 2002; Dutt et al., 2005; 
Patil et al., 2005). SLCMV-Adi, an isolate from southwestern India (Adivaram, Kerala) has been analyzed earlier, focusing mainly on the CR and the infectivity of the DNA components using agro-inoculation, a method of introduction of the viral DNA into plants using Agrobacterium-mediated inoculation of viral DNA cloned as a partial dimer (Grimsley et al., 1986; Dutt et al., 2005). In this study, we have analyzed the DNA-A component of an SLCMV isolate obtained from Attur, Tamil Nadu, India, for the presence of known functional domains of begomoviral proteins. We have compared the sequence with other begomoviral sequences available in the databases from India and elsewhere to study its phylogenetic relationship and have standardized the procedure for biolistic inoculation of the laboratory host $N$. benthamiana, in which DNA molecules are inoculated to plants using pressurized metal microcarriers (Kikkert et al., 2004),

\section{Materials and Methods}

Genomic DNA isolation: Symptomatic cassava stem cuttings were collected in the year 2009 from field locations near Attur, district Salem, Tamil Nadu, India. The cuttings were planted in greenhouses of University of Delhi South Campus, New Delhi and fresh leaves, sprouting from the above cuttings were used for the extraction of total genomic DNA using SDS method (Dellaporta et al., 1983). Symptomatic leaves of $N$. benthamiana, following biolistic inoculation were used to isolate DNA using SDS method.

Rolling circle amplification (RCA) of total DNA extracted from infected plants. Viral DNA was amplified by Rolling circle amplification (RCA) using the TempliPhi ${ }^{\mathrm{TM}}$ Amplification Kit (GE Healthcare, Amersham) as per manufacturer's recommendation.

Cloning and sequencing. Digestion with Pst $\mathrm{I}$ was performed to linearize the RCA product and the resulting $2.7 \mathrm{~kb}$ fragment was cloned in pTZ57R vector (MBI Fermentas) and completely sequenced using a primer walking strategy (Haible et al., 2006; Homs et al., 2008). DNA sequencing was performed at the University of Delhi South Campus sequencing facility.

Sequence analysis. Begomoviral genes and their predicted amino acid sequences were searched by BLAST at NCBI server (www. ncbi.nlm.nih.gov/) and the software Gene Runner version 3.05. Nucleotide identities between cloned viral DNA molecule and other selected begomoviruses were analysed by the ClustalW method and NCBI BLAST server (Thompson et al., 1994).

Phylogenetic analysis. A phylogenetic tree (1000 bootstrap replications) was constructed of the cloned viral DNA and sequences of other begomoviral DNA-As, downloaded from nucleic acid sequence databases, by using the Neighbour-joining method in MEGA4.0 software (Tamura et al., 2007). GenBank Acc. Nos. of DNA-A of various begomoviruses used for sequence analysis and for the construction of the phylogenetic tree are given in Table 1.

Southern blot analysis: Genomic DNA isolated from the leaves of plants biolistically inoculated with the SLCMV DNA-A were size separated by gel electrophoresis, transferred to a nylon membrane and hybridized using standard methods (Sambrook and Russel, 2001). DNA fragments were labeled using Amersham ${ }^{\mathrm{TM}}$ Megaprime DNA Labeling System (GE Healthcare) kit and used as probe.

Infectivity analysis. For infectivity analysis, the viral insert (2.7 $\mathrm{kb}$ ) was released from the vector backbone by digesting with PstI, self-ligated, amplified by RCA and used for biolistic inoculation by Bio-Rad hand-held biolistic device (Catalog No. 165-2431 and 165-2432). The distance between leaf tissue and biolistic device was kept at $2 \mathrm{~cm}$. N. benthamiana plants were grown for 30 days at $28^{\circ} \mathrm{C}$ and $12 \mathrm{hr}$ photoperiod and inoculated at the third or fourth true leaf stage. Viral replication in inoculated plants was verified by Southern blot analysis. A DNA fragment representing the AV1 of the viral clone was used as a radioactive probe.

\section{Results and Discussion}

\section{General feature of begomoviruses associated with CMD}

DNA sequence analysis of the cloned viral DNA revealed 2758 nucleotides, which shared 99\% identity with SLCMVAdivaram DNA-A [AJ579307]. Hence the virus was considered to be an isolate of SLCMV and was given the descriptor SLCMV-IN[IN:Attur:09], (SLCMV-Attur, GenBank Acc. No. KC424490), named after Attur, the nearest town from the site of collection of the isolate. In SLCMV-Attur DNA-A, there were seven ORFs; two in the virion-sense ( $A V 1 \& A V 2)$, and five in the complementary-sense orientation (AC1-AC5), typical of Old World begomoviruses. The nucleotide coordinates of $A V 1$ and AV2 were 297-1067 and 137-493, encoding proteins of predicted $256(29.8 \mathrm{kDa})$ and 118 amino acid residues (13.6 $\mathrm{kDa}$ ), respectively. The nucleotide coordinates of $A C 1, A C 2$, AC3, AC4, and AC5 were 1546-2601, 1209-1616, 1064-1468, 2145-2447, and 327-812, respectively, encoding proteins with predicted $352(39.5 \mathrm{kDa}), 135(15.0 \mathrm{kDa}), 134(15.8 \mathrm{kDa}), 100$ $(10.8 \mathrm{kDa})$, and $161(18.02 \mathrm{kDa})$ amino acid residues.

\section{Motif analysis}

All functional domains identified in the AV1 protein homologs in other begomoviruses were present in SLCMV-Attur at comparable positions, for example ${ }^{16} \mathrm{KVRRR}^{20}$ and ${ }^{51} \mathrm{RK}^{52}$ (nuclear localization, Sigrid et al., 2001). Domains ${ }^{14} \mathrm{FLTYP}^{18}$ (binding to dsDNA), ${ }^{56} \mathrm{HLH}^{58}$ (metal-binding site that may be involved in protein conformation and DNA cleavage), ${ }^{100}$ DVKXYXXKD ${ }^{108}$ (DNA cleavage, Beverly and HanleyBowdoin, 1998) and ${ }^{220}$ GDSRTGKT ${ }^{227}$ (ATP binding, Desbiez et al., 1995), found in AC1 were also present. Similarly for AC2, ${ }^{29} \mathrm{RRRR}^{32}$ (nuclear localization signal), $\mathrm{C}^{37}, \mathrm{C}^{39}, \mathrm{H}^{44}, \mathrm{H}^{54}$, and $\mathrm{C}^{47}$ (promoter activation and silencing suppression) were all present in SLCMV-Attur (Daniela et al., 2005; Hartitz et al., 1999). 
Table 1. Overall sequence identities of 44 geminiviral DNA-A sequences from Indian subcontinent and elsewhere with the DNA-A of SLCMV-Attur

\begin{tabular}{|c|c|c|c|}
\hline Full name & Abbreviation name & $\begin{array}{c}\text { EMBL } \\
\text { Acc. No. }\end{array}$ & $\begin{array}{c}\text { Percentage } \\
\text { nucleotide } \\
\text { identity }\end{array}$ \\
\hline Bean golden yellow mosaic virus - [Puerto Rico-Japan] & BGYMV-PR:JR & D00201.1 & 65 \\
\hline Bhendi yellow vein mosaic virus - India[India;Madurai] & BYVMV-IN[IN:Mad] & AF241479.1 & 76 \\
\hline Bhendi yellow vein mosaic virus - Pakistan[Pakistan:Multan301:1996 & BYVMV-PK[PK:M301:96] & AJ002453.1 & 76 \\
\hline Cowpea golden mosaic virus - [Nigeria:Nsukka:1990] & CGMV-[NG:Nsu:90] & AF029217.1 & 68 \\
\hline Chilli leaf curl virus isolate Taq4 - Oman[Oman:2005] & ChiLCV-OM[OM:05] & JN604495.1 & 77 \\
\hline Cotton leaf curl Bangalore virus [India:Bangalore:OY136A:2005] & CoLCBV-IN[IN:Ban:05] & GU112003.1 & 77 \\
\hline Cotton leaf curl Multan virus - Hisar[India:New Delhi:1999] & CLCuMV-His[IN:ND:99] & AY765256.1 & 76 \\
\hline Cotton leaf curl Multan virus - Hisar [Pakistan:Faisalabad 3] & CLCuMV-His[PK:Fai3] & AJ132430.1 & 76 \\
\hline Cucurbit leaf crumple virus - [United States of America:Arizona:1991] & CuLCrV-[US:Ari:91] & AF256200.4 & 66 \\
\hline East African cassava mosaic Kenya virus - [Kenya:Kathiana:K300:2002] & EACMKV-[KE:Kat:K300:02] & AJ717580.1 & 73 \\
\hline East African cassava mosaic Zanzibar virus - [Kenya:Felunzi:K19:2001] & EACMZV-[KE:Fel:K19:01] & AJ717562.1 & 73 \\
\hline Horsegram yellow mosaic virus - [India:Bangalore:French bean:2004] & HgYMV-[IN:Ban:FB:04] & AM932425.1 & 67 \\
\hline Indian cassava mosaic virus - India [India:Maharashstra:1988] & ICMV-IN[IN:Mah:88] & AJ314739.1 & 85 \\
\hline Jatropha yellow mosaic India virus & JYMIV-IN & FJ177030.2 & 76 \\
\hline Kudzu mosaic virus - [Vietnam:Hoabinh:2005] & KuMV-[VN:Hoa:05] & DQ641690.1 & 68 \\
\hline Mungbean yellow mosaic virus - [Pakistan:14] & MYMIV-[PK:14] & AJ512495.1 & 66 \\
\hline Malvastrum leaf curl virus - [China:Guangxi 87:2004] & MaLCV-[CN:Gx87:04] & AJ971263.1 & 74 \\
\hline Mesta yellow vein mosaic Bahraich virus - [India:Bhanga:2008] & MEYVMBV-IN[IN:Bha:08] & FJ159268.1 & 76 \\
\hline Mungbean yellow mosaic India virus Indonesia isolate Bogor & MuYMIVI-[ID:11] & JN368432.1 & 67 \\
\hline Mungbean yellow mosaic India virus - [India:Varanasi:Dolichos] & MYMIV-[IN:Var:Dol] & AY547317.1 & 66 \\
\hline Mungbean yellow mosaic India virus - [Pakistan:106] & MYMIV-[PK:106] & AJ512498.1 & 66 \\
\hline Okra leaf curl virus - [Mali] & OLCV-[ML:07] & EU024119.1 & 73 \\
\hline Okra yellow mosaic Mexico virus - [Mexico:Mazatepec 3:2004] & OYMMV-[MX:Maz3:04] & DQ022611.1 & 68 \\
\hline Papaya leaf curl virus isolate Lucknow & PaLCuV-IN[IN:Luc] & JN135233.1 & 77 \\
\hline Papaya leaf curl virus - Pakistan[Pakistan:Cotton:2002] & PaLCuV-PK[PK:Cot:02] & AJ436992.1 & 76 \\
\hline Rhynchosia yellow mosaic virus - [Pakistan:Lahore] & RYMV-[PK:Lah:09] & AM999981.1 & 68 \\
\hline South African cassava mosaic virus - [Zimbabwe:Muzarabani] & SACMV-[ZW:Muz] & AJ575560.1 & 74 \\
\hline Sida leaf curl virus - [China:Hainan 57:2004] & SiLCuV-[CN:Hn57:04] & AM050730.1 & 73 \\
\hline Sida yellow vein Madurai virus - [India:Madurai:2005] & SiYVMaV-[IN:Mad:05] & AM259382.1 & 74 \\
\hline Sri Lankan cassava mosaic virus - India[India:Adivaram] & SLCMV-IN[IN:Adi] & AJ579307.1 & 99 \\
\hline Sri Lankan cassava mosaic virus - Sri Lanka [Sri Lanka:Colombo:1998] & SLCMV-LK[LK:Col:98] & AJ314737.1 & 93 \\
\hline Squash leaf curl China virus - India [India:Coimbatore:Pumpkin] & SLCCNV-IN[IN:Coi:Pum] & AY184487.1 & 73 \\
\hline Squash leaf curl virus isolate YL segment DNA A[Taiwan:Yunlin] & SLCCV-TW[TW:Yun] & EU479710.1 & 74 \\
\hline Sweet potato leaf curl Bengal virus - [India:West Bengal:2008] & SWPLCBV-IN[IN:WB:08] & FN432356.2 & 64 \\
\hline Tomato leaf curl Bangladesh virus - [Bangladesh:2] & ToLCBDV-[BD:2] & AF188481.1 & 77 \\
\hline Tomato leaf curl Bangalore virus - [India:Kerala IV:2005] & ToLCBV-IN[IN:Ker:05] & DQ887537.1 & 75 \\
\hline Tomato leaf curl Pakistan virus isolate Rahim Yaar Khan 1 clone PT7 & ToLCPV-[PK:RYK:06] & DQ116884.1 & 79 \\
\hline Tomato leaf curl Sinaloa virus - [Nicaragua:Santa Lucia] & ToLCSinV-[NI:SL] & AJ608286.1 & 70 \\
\hline Tomato leaf curl Philippines virus isolate P36 [Philippines: Benguet:08] & ToLCuPV-[PH:Ben:08] & EU487029.2 & 72 \\
\hline Tomato yellow leaf curl Thailand virus - A [Thailand:2] & ToYLCTHV-[TH:2] & AF141922.1 & 70 \\
\hline Tomato yellow leaf curl virus - Israel [Israel:Rehovot:1986] & TYLCV-IL[IL:Reo:86] & X15656 & 70 \\
\hline Tomato yellow leaf curl virus - Iran [Iran:Iranshahr:1998] & TYLCV-IR[IR:Ira:86] & AJ132711.1 & 73 \\
\hline Tomato yellow leaf curl virus - Mild [Spain:72:1997] & TYLCV-Mld-[ES72:97] & AF071228.1 & 75 \\
\hline Velvet bean severe mosaic virus-Lucknow & VBSMV-IN[IN:UP:Luc] & FN543425.1 & 66 \\
\hline
\end{tabular}

\section{Phylogenetic analysis}

Phylogenetic analysis revealed that SLCMV-Attur shared 64-99 percent sequence identities with 44 other begomoviral DNA-A sequences (Table 1) and was closely related to begomoviruses infecting plants from the families
Caricaceae, Euphorbiaceae, Malvaceae and Solanaceae from Indian subcontinent (Fig. 1). SLCMV-Attur had a distant relationship with legume-infecting (Olufemi et al., 2010) and cucurbit-infecting begomoviruses from the Indian subcontinent and most begomoviruses from outside the Indian subcontinent. 


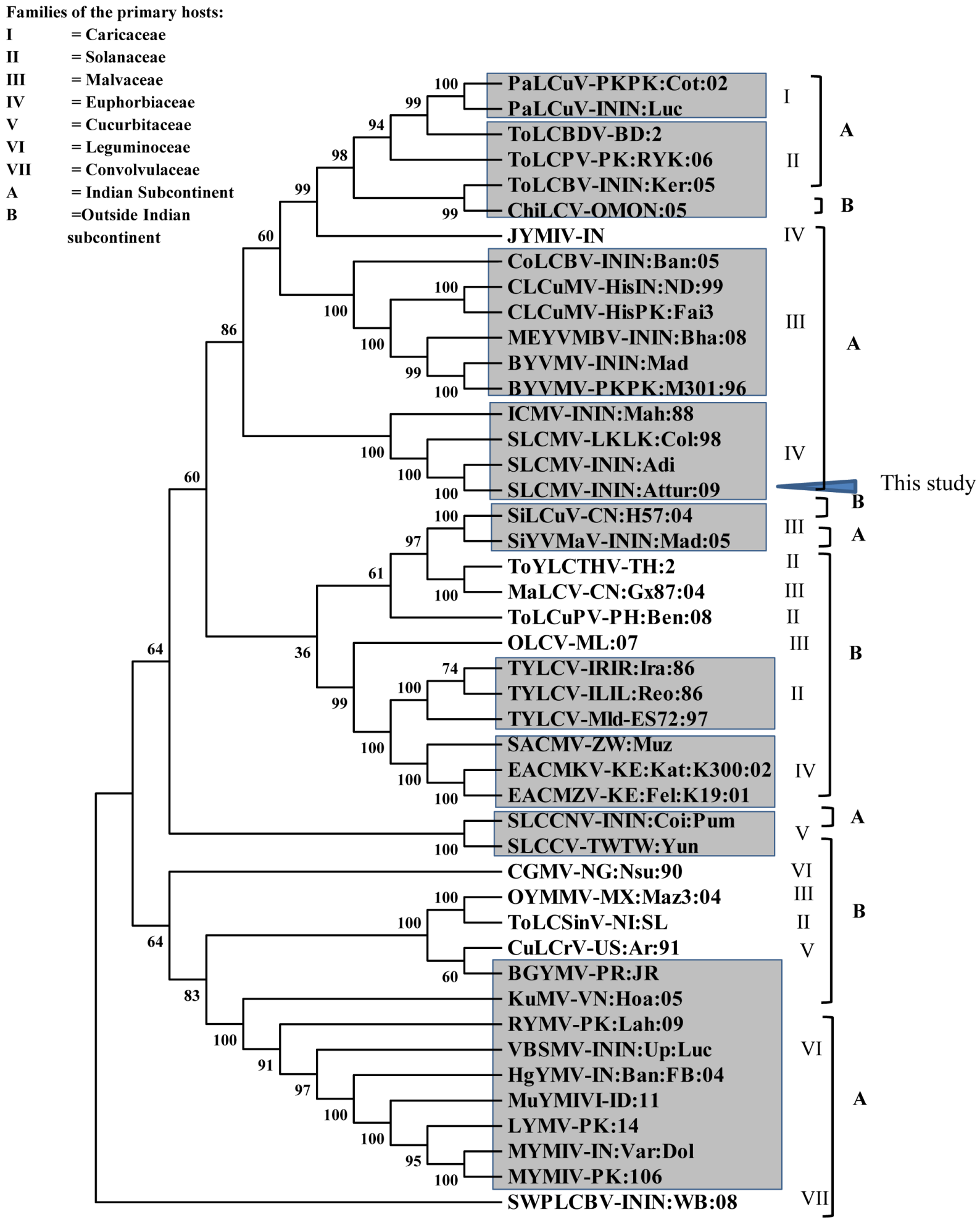

Fig. 1

Dendrogram showing the phylogeny of the complete nucleotide sequence of SLCMV-Attur DNA-A (shown in arrow) with begomoviral nucleotide sequences reported from the Indian subcontinent and from the outside of the Indian subcontinent

Horizontal distances are proportional to the sequence distances and vertical distances are arbitrary. A bootstrap analysis with 1,000 replicates was performed. The Families, to which the primary hosts belong, are indicated for each virus. Virus abbreviations are the same as in Table 1. 


\section{Infectivity of cloned component of SLCMV by Biolistic inoculation}

When N. benthamiana plants were inoculated with $1000 \mathrm{ng}$ of RCA-amplified circularized SLCMV-Attur DNA-A using the biolistic device, 56 out of 66 plants showed stunting and downward leaf curling between 21 to 28 days post-inoculation, when the DNA was inoculated under the pressure of 200 pounds per square inch (psi) (Fig. 2, Table 2). With the same DNA, at the pressure of $150 \mathrm{psi}$, the symptoms were mild downward leaf curling and no symptoms appeared at the pressure of 100 psi (Table 2). Eight inoculated plants showing severe symptoms were analyzed for the accumulation of SLCMV DNA by Southern blot. Seven of them gave the appropriate signals indicating viral DNA accumulation (Fig. 3). Begomoviral DNA molecules from three such plants were cloned and sequenced. The sequence (around 700 bp nucleotides) matched perfectly with SLCMV-Attur DNA-A. The symptoms were markedly different from the upward leaf rolling and vein swelling reported after infection with SLCMV-Adi via agroinoculation (Dutt et al., 2005; Mittal et al., 2009).

Cassava is a vegetatively propagated crop, and the close phylogenetic relationship between SLCMV-Attur and other SLCMV strains indicates that they have remained genetically uniform over time and across the regions where SLCMV thrives in India. This may be partly contributed to by the possible movement of infected cassava propagules. The low genetic identity of SLCMV-Attur with SLCMV-Colombo, an isolate reported from Sri Lanka, (Table 1) could be because of the geographical isolation of Sri Lanka from southern India and the lack of exchange of infected cassava propagules. The closer phylogenetic relationship of Indian begomoviruses with SLCMV-Attur than with those from outside the Indian subcontinent (Table 1, Fig. 1) points towards the involvement

Table 2. Infectivity of SLCMV-Attur DNA-A on N. benthamiana plants using three pressure conditions and two DNA quantities in biolistic inoculation after 21-28 days post-inoculation

\begin{tabular}{ccccc}
\hline $\begin{array}{c}\text { Experi- } \\
\text { ment } \\
\text { No. }\end{array}$ & $\begin{array}{c}\text { No. of } \\
\text { symptomatic/ } \\
\text { No. of inoculated } \\
\text { plants }\end{array}$ & $\begin{array}{c}\text { Pressure } \\
(\mathbf{p s i})\end{array}$ & Symptoms ${ }^{\mathbf{a}}$ & $\begin{array}{c}\text { Amount of } \\
\text { DNA (ng) } \\
\text { used per } \\
\text { plant }\end{array}$ \\
\hline 1 & $14 / 15$ & 200 & SD, DC & 1000 \\
2 & $13 / 15$ & 200 & SD, DC & 1000 \\
3 & $11 / 15$ & 200 & SD, DC & 1000 \\
4 & $12 / 15$ & 200 & SD, DC & 1000 \\
5 & $6 / 6$ & 200 & SD, DC & 1000 \\
6 & $5 / 15$ & 150 & MS, DC & 1000 \\
7 & $1 / 3$ & 150 & MS, DC & 700 \\
8 & $1 / 3$ & 150 & MS, DC & 700 \\
9 & $2 / 6$ & 150 & MS, DC & 700 \\
10 & $1 / 12$ & 150 & MS, DC & 700 \\
11 & $3 / 12$ & 150 & MS, DC & 700 \\
12 & $0 / 15$ & 100 & No symptoms & 1000 \\
13 & $0 / 12$ & 200 & No symptoms & 0 \\
\hline
\end{tabular}

${ }^{a} \mathrm{SS}=$ severe stunting, $\mathrm{DC}=$ downward leaf curling, $\mathrm{MS}=$ mild stunting.

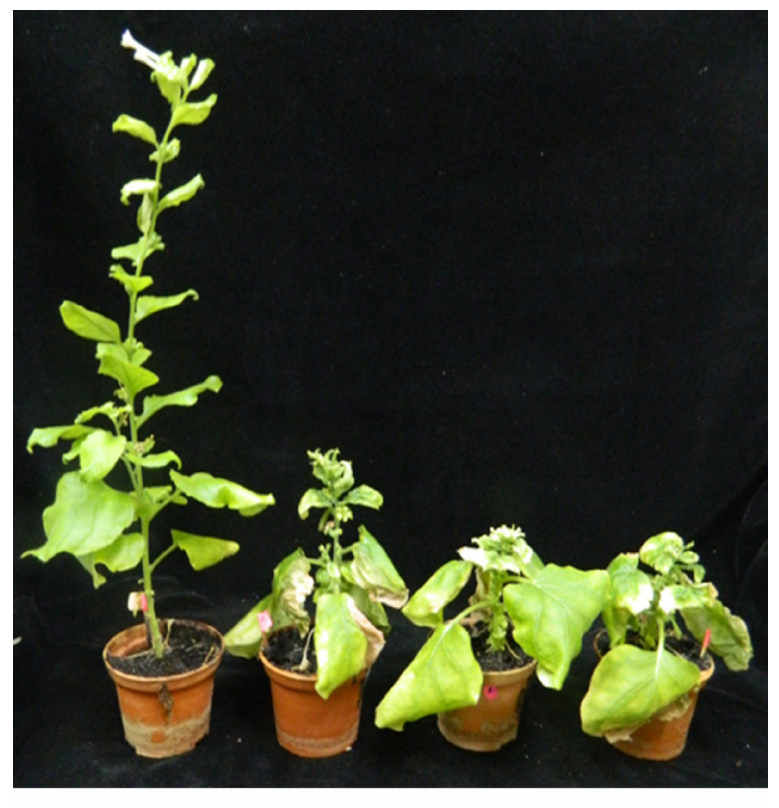

(a)

(b)

(c)

(d)

Fig. 2

Symptoms produced by biolistic inoculation of $N$. benthamiana using SLCMV-Attur DNA-A, 30 days post-inoculation

Plant (a), control inoculation using only gold particles; plants (b-d), inoculation using SLCMV-Attur DNA-A. All three plants shown in (b-d) show severe stunting.

\section{$\begin{array}{lllllllll}1 & 2 & 3 & 4 & 5 & 6 & 7 & 8 & -\mathrm{ve}+\mathrm{ve}\end{array}$}

OC

Sc

SS

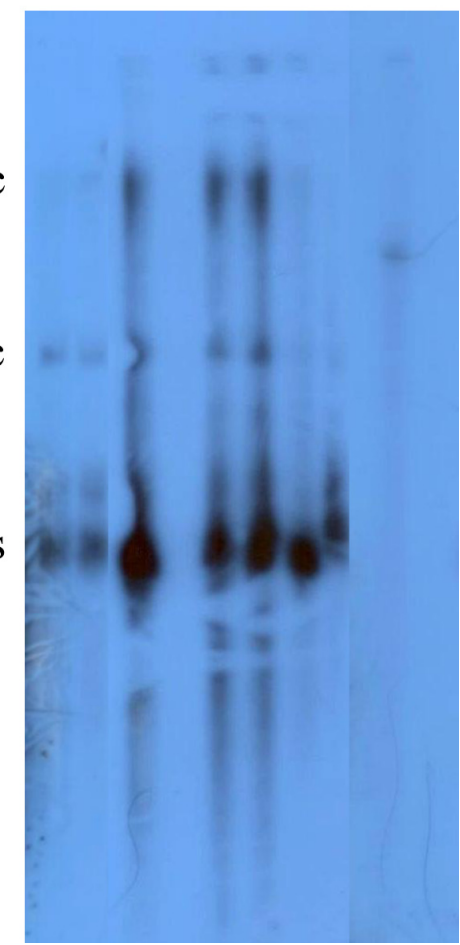

Fig. 3

Southern hybridization analysis showing replication of viral DNA in systemic leaf tissue of $N$. benthamiana plants biolistically inoculated with SLCMV-Attur DNA-A at 30 days postinoculation

The blot was probed with a DNA fragment encoding the coat protein. Lanes 1-8 total DNA from leaves inoculated with SLCMVAttur DNA-A, -ve, DNA from leaves inoculated with only microcarrier particles, +ve, cloned SLCMV DNA-A. Positions of open circular (ocDNA), super coiled ( $\mathrm{scDNA}$ ) and single stranded (ssDNA) viral DNA forms are indicated. 
of the insect vector, the single polyphagous whitefly species, in the process of shaping the begomoviral genomes. The genetic isolation of begomoviruses from cucrbitaceous and leguminous plants is probably due to a host range barrier or lack of movement of whitefly vectors between these hosts and other plants, preventing the genetic exchange between these groups of viruses (Qazi et al., 2007).

The downward leaf curling symptoms observed in the biolistic method, as opposed to upward leaf-rolling and vein swelling in agroinoculation, possibly results from DNA delivery into the epidermal or mesophyll cells, whereas the agroinoculation delivers it into the vasculature of the stem or the petiole, triggering different sets of interactions between the viral and host proteins or RNAs, thus giving rise to different symptoms. This hypothesis, however, needs deeper investigation.

An earlier report has described biolistic inoculation of cassava plants using SLCMV-Adi (Dutt et al., 2005). The method of biolistic inoculation described in this paper gives more details on the conditions to be used to obtain optimal infections and can be used as the starting point for optimizing its infectivity on the natural host cassava.

\section{Future perspective}

Biolistic delivery of SLCMV DNA to N. benthamiana opens up the possibility of analysis of its gene functions by site-directed mutagenesis.

Acknowledgement. AKK gratefully acknowledges fellowships from University of Delhi and Department of Biotechnology, Government of India. This work was funded by the grant number BT/ PR6914/PBD/16/644/2005-IV by Department of Biotechnology, Government of India to ID and RR.

\section{References}

Abraham A (1956): Tapioca cultivation in India. Farm Bulletin No. 17. Indian Council of Agricultural Research, New Delhi, p. 20.

Alagianagalingam MN, Ramakrishnan K (1966): Cassava mosaic in India. South Indian Horiculture 14, 441-448.

Azzam O, Frazer J, Delarosa D, Beaver JS, Ahlquist P, Maxwell DP (1994): Whitefly transmission and efficient ssDNA accumulation of bean golden mosaic geminivirus require functional coat protein. Virology 204, 289-296. http:// dx.doi.org/10.1006/viro.1994.1533

Beverly MO, Hanley-Bowdoin L (1998): Conserved sequence and structural motifs Contribute to the DNA binding and cleavage activities of a geminivirus replication protein. J. Biol. Chem. 273, 24448-24456. http://dx.doi.org/10.1074/ jbc.273.38.24448

Castillo JN, Olive EF, Campos SS (2011): Emerging virus diseases transmitted by whiteflies. Annu. Rev. Phytopathol. 49,
219-248. http://dx.doi.org/10.1146/annurev-phyto072910-095235

Daniela T, Rajeswaran R, Shivaprasad PV, Akbergenov R, Edward J. Oakeley K, Veluthambi, Thomas H, Pooggin MM (2005): Suppression of RNA Silencing by a geminivirus nuclear protein, $\mathrm{AC} 2$, correlates with transactivation of host genes. J. Virol. 79, 2517. http://dx.doi.org/10.1128/ JVI.79.4.2517-2527.2005

Dellaporta SL, Wood J, Hicks JB (1983): A plant DNA mini-minipreparation: version II. Plant. Mol. Biol. Rep. 1, 19-21. http://dx.doi.org/10.1007/BF02712670

Desbiez C, Davidt C, Metfouchit A, Laufs J, Gorenborn B (1995): Rep protein of tomato yellow leaf curl geminivirus has an ATPase activity required for viral DNA replication. Proc. Natl. Acad. Sci. USA 92, 5640-5644. http://dx.doi. org/10.1073/pnas.92.12.5640

Dutt N, Briddon RW, Dasgupta I (2005): Identification of a second begomovirus, Sri Lankan cassava mosaic virus, causing cassava mosaic disease in India. Arch. Virol. 150, 21012108. http://dx.doi.org/10.1007/s00705-005-0579-9

Fauquet CM, Briddon RW, Brown JK, Moriones E, Stanley J, Zerbini M, Zhou X (2008): Geminivirus strain demarcation and nomenclature. Arch. Virol. 153, 783-821. http://dx.doi. org/10.1007/s00705-008-0037-6

Grimsley N, Hohn B, Hohn T, Walden R (1986): Agroinfection, an alternative route for viral infection of plants by using the Ti plasmid. Proc. Natl. Acad. Sci. USA 83, 3282-3286. http://dx.doi.org/10.1073/pnas.83.10.3282

Haible D, Kober S, Jeske H (2006): Rolling circle amplification revolutionizes diagnosis and genomics of geminiviruses. J. Virol. Methods 135, 9-16. http://dx.doi.org/10.1016/j. jviromet.2006.01.017

Harrison BD, Robinson DJ (1999): Natural genomic and antigenic variation in whitefly-transmitted geminiviruses (begomoviruses). Annu. Rev. Phytopathol. 37, 369-398. http:// dx.doi.org/10.1146/annurev.phyto.37.1.369

Homs M, Kober S, Kepp G, Jeske H (2008): Mitochondrial plasmids of sugar beet amplified via rolling circle method detected during curtovirus screening. Virus Res. 136, 124-129. http://dx.doi.org/10.1016/j.virusres.2008.04.027

Kikkert JR, Vidal JR, Reisch BI (2004): STable transformation of plant cells by particle bombardment/biolistics. Methods Mol. Biol. 286, 61-78.

Jupin I, Hericourt F, Benz B, Gronenborn B (1995): DNA replication specificity of TYLCV geminivirus is mediated by the amino-terminal 116 amino acids of the Rep protein. FEBS. Lett. 362, 116-120. http://dx.doi.org/10.1016/00145793(95)00221-T

Kheyr-Pour A, Bendahmane M, Matzeit V, Accotto GP, Crespi S, Gronenborn B (1991): Tomato yellow leaf curl virus from Sardinia is a whitefly-ransmitted monopartite geminivirus. Nucleic Acids Res. 19, 6763-6769. http://dx.doi. org/10.1093/nar/19.24.6763

Hartitz MD, Sunter G, Bisaro DM (1999): The tomato golden mosaic virus transactivator (TrAP) is a single-stranded DNA and zinc-binding phosphoprotein with an Acidic Activation Domain. Virology 263, 1-14. http://dx.doi.org/10.1006/ viro.1999.9925 
Mittal D, Borah BK, Dasgupta I (2009): Agroinoculation of cloned Sri Lankan cassava mosaic virus DNA to Arabidopsis thaliana, Nicotiana tabacum and cassava. Arch. Virol. 153, 2149-2155. http://dx.doi.org/10.1007/s00705-008 $\underline{-0238-\mathrm{Z}}$

Morris B, Richardson K, Eddy P, Zhan XC, Haley S, Gardner R (1991): Mutagenesis of the AC3 open reading frame of African cassava mosaic virus DNA A reduces DNA B replication and ameliorates disease symptoms. J. Gen. Virol. 72, 1205-1213. http://dx.doi.org/10.1099/0022$\underline{1317-72-6-1205}$

Olufemi JA, Lavakumar P, Mgbechi-Ezeri JU, Naidu RA (2010): Two new 'legumoviruses' (genus Begomovirus) naturally infecting soybean in Nigeria. Arch. Virol. 155, 643-656. http://dx.doi.org/10.1007/s00705-010-0630-3

Patil BL, Fauquet CM (2009): Cassava mosaic geminiviruses: actual knowledge and perspectives. Mol. Plant. Pathol. 10, 685-701. http://dx.doi.org/10.1111/j.1364-3703 $.2009 .00559 . \mathrm{x}$

Patil BL, Rajasubramaniam S, Bagchi C, Dasgupta I (2005): Both Indian cassava mosaic virus and Sri Lankan cassava mosaic virus are found in India and exhibit high variability as assessed by PCR-RFLP. Arch. Virol. 150, 398-397. http:// dx.doi.org/10.1007/s00705-004-0399-3

Qazi J, Ilyas M, Mansoor S, Briddon RW (2007): Legume yellow mosaic viruses: genetically isolated begomoviruses. Mol. Plant. Pathol. 8, 343-348. http://dx.doi.org/10.1111/ j.1364-3703.2007.00402.x

Sambrook J, Russel R (2001): Molecular Cloning: A Laboratory Manual. Cold Spring Harbor Press, Cold Spring Harbor, NY.

Sanderfoot AA, Lazarowitz SG (1996): Getting it together in plant virus movement: cooperative interactions between bipartite geminivirus movement proteins. Trends. Cell.
Biol. 6, 353-358. http://dx.doi.org/10.1016/0962-8924(96)10031-3

Saunders K, Nazeera S, Mali VR, Malathi VG, Briddon RW, Markham PG, Stanley J (2002): Characterisation of Sri Lankan cassava mosaic virus and Indian cassava mosaic virus: evidence for acquisition of a DNA B component by a monopartite begomovirus. Virology 293, 63-74. http:// dx.doi.org/10.1006/viro.2001.1251

Sigrid U, Martin HE, Margit R, and Thomas F (2001): Subcellular targeting of the coat protein of African cassava mosaic geminivirus. Virology 286, 373-383. http://dx.doi. org/10.1006/viro.2001.1003

Sung YK, Coutts RH (1995): Mutational analysis of potato yellow mosaic geminivirus. J. Gen. Virol. 76, 1773-1780. http:// dx.doi.org/10.1099/0022-1317-76-7-1773

Tamura K, Dudley J, Nei M, Kumar S (2007): Mega4: Molecular Evolutionary Genetics Analysis (MEGA) software version 4.0. Mol. Biol. Evol. 24, 1596-1599. http://dx.doi. org $/ 10.1093 / \mathrm{molbev} / \mathrm{msm} 092$

Thompson JD, Higgins DG, Gibson TJ. CLUSTAL W (1994): Improving the sensitivity of progressive multiple sequence alignment through sequence weighting, positionspecific gap penalties and weight matrix choice. Nucleic Acids Res. 22, 4673-4680. http://dx.doi.org/10.1093/ $\underline{\text { nar/22.22.4673 }}$

Thresh JM, Otim-Nape GW, Legg JP, Fargette D (1997): African cassava mosaic virus disease: the magnitude of the problem. Afr. J. Root. Tuber. Crops. 2, 13-19.

Vanitharani R, Chellappan P, Pita JS, Fauquet C (2004): Differential roles of $\mathrm{AC} 2$ and $\mathrm{AC} 4$ of cassava geminiviruses in mediating synergism and suppression of posttranscriptional gene silencing. J. Virol. 78, 9487-9498. http://dx.doi. org/10.1128/JVI.78.17.9487-9498.2004 